\section{Effects of UV-C radiation on common dandelion and purple coneflower: First results}

\author{
Donato Castronuovo, Adriano Sofo, \\ Stella Lovelli, Vincenzo Candido, \\ Antonio Scopa
}

School of Agricultural, Forestry, Food and Environmental Sciences, University of Basilicata, Potenza, Italy

\begin{abstract}
Ultraviolet-C (UV-C) light $(100 \leq \lambda \leq$ $280 \mathrm{~nm}$ ) is a ionizing radiation that can damage living organisms. An experiment was conducted on plants of common dandelion (Taraxacum officinale Weber, $T$. Densleonis Desf.) and purple coneflower [Echinacea purpurea, (L.) Moench] irradiated with UV-C at different exposition times, under controlled conditions and grown in self-produced characterized compost, to assess the effect of different doses UV-C radiation on some physiological parameters. Trials have been carried out using a black chamber equipped with an UV-C lamp in which plants were divided in four groups on the basis of UV-C irradiation period $(10,30,60$, and $120 \mathrm{~min})$. Non-irradiated plants were kept as controls. Plant photosynthetic performance, chlorophyll content (SPAD) and some morphologic traits were recorded before, immediately after irradiations and 20 days weeks later. The effects on photosynthetic performances and chlorophyll contents (SPAD) were evaluated and compared with data obtained in similar experiments where tomato plants were irradiated at different times with UV$\mathrm{C}$ light. In both species, SPAD values decreased as the irradiation period became longer. The two species showed different gas exchange dynamics, depending on the UV-C exposure time. Two months after the UV-C irradiation, plant dry weight measured at 120-min UV-C exposure was significantly lower than the control.
\end{abstract}

\section{Introduction}

Ultraviolet (UV) light is an electromagnetic radiation with a wavelength in the range of $100 \leq \lambda \leq 280 \mathrm{~nm}$, characterized by elevate energy values and high ionization capacity. ${ }^{1}$ UV-C has on living organisms a strong germicidal action, ${ }^{2}$ an acute oxidative performance and a high genetic mutation rate. ${ }^{3}$ On plants, UV-C exposure can cause negative effects on morphology, flowering, pollination, transpiration and photosynthesis. ${ }^{4} \mathrm{UV}-\mathrm{C}$ light is damaging to living tissue because free radicals produced are very energetic, highly absorbed tissues and very damaging at molecular levels. ${ }^{5}$ In fact, the exposition of organic matter or biological compounds to ultraviolet light causes alteration of plant growing, breakage of chemical bonds, and cell death due to DNA mutations. ${ }^{6}$

Fortunately, UV-C radiation is efficiently filtered by the ozone layer in the stratosphere so that the amount of this radiation reaching the Earth's surface is very low. ${ }^{7}$ In spite of this, some chemicals, such as chlorofluorocarbons (CFC), which have been released into the atmosphere and have contributed to the depletion of ozone protective layer. Therefore, in the future UV-C radiation could increase as the result of stratospheric ozone depletion due to atmospheric pollution. In fact, the stratospheric ozone layer reduction highlights the ecological implication of increasing UV-C radiation on natural ecosystems and on agricultural productions. ${ }^{8}$ In this scenario, characterized by an increasing trend of UV-C flux on Earth's surface, the study of the effect of this radiation on some crops becomes relevant.

Therefore, it is important to understand how plants respond to UV-C in terms of stress resistance, growth and development capacity and, in particular, the effects of low levels of exposition to UV-C on plants physiological processes and morphology. The protective mechanisms of plants to UV$\mathrm{C}$ stress could include the formation of phenolic compounds in the outer epidermal tissues, the production of antioxidant compounds and the increased activity of antioxidant enzymes for repairing plant damage by UV radiation. ${ }^{9}$

In this study, common dandelion (Taraxacum officinale Weber, T. Densleonis Desf.) and purple coneflower [Echinacea purpurea, (L.) Moench], both belonging to the Asteraceae family, were chosen to be studied due to their importance and usefulness for nutraceuticals purposes. In particular, common dandelion is a perennial herbaceous plant spread worldwide up to $2,000 \mathrm{~m}$ a.s.l., so to be considered sometimes as a weed. It is a perennial herbaceous plant with several health-promoting effects, such as diuretic, laxative and tonic, and it is used against dyspepsia, anorexia and high levels of cholesterol. ${ }^{10}$ Purple coneflower is a perennial plant native of the prairies of Canada and of the United States. This plant is well known as a medicinal plant for its effects in strengthening the immune system and for its antiviral activity. ${ }^{11,12}$ In a previous study, these species responded differ-
Correspondence: Adriano Sofo, School of Agricultural, Forestry, Food and Environmental Sciences, University of Basilicata, Viale dell'Ateneo Lucano, 10, 85100 Potenza, Italy

Tel.: +39.0971.206228 - Fax: +39.0971.204307.

E-mail: adriano.sofo@unibas.it

Key words: dry matter, chlorophyll content, gas exchange; photosynthesis, ozone layer.

Acknowledgements: This research was carried out in the framework of the project 'Smart Basilicata' (Contract n. 6386 - 3, 20 July 2016). Smart Basilicata was approved by the Italian Ministry of Education, University and Research (Notice MIUR n.84/Ric 2012, PON 2007-2013 of 2 March 2012) and was funded with the Cohesion Fund 2007-2013 of the Basilicata Regional authority.

Contributions: the authors contributed equally.

Conflict of interest: the authors decalre no potential conflict of interest.

Received for publication: 8 June 2017. Accepted for publication: 16 June 2017.

This work is licensed under a Creative Commons Attribution-NonCommercial 4.0 International License (CC BY-NC 4.0).

(C) Copyright D. Castronuovo et al., 2017

Licensee PAGEPress srl, Italy

International Journal of Plant Biology 2017; 8:7255 doi:10.4081/pb.2017.7255

ently when irradiated with different light sources, and particularly with Fluora and LEDs. ${ }^{13}$

On this basis, this research is aimed at investigating the effects of UV-C light the photosynthetic and physiological responses of these two rustic plants. Plants of both the species were tested under UV-C for different exposition times to evaluate he effects on photosynthetic performances, chlorophyll contents (SPAD) and same morphologic traits.

\section{Materials and Methods \\ Plant growth conditions and treat- ments}

Seeds of common dandelion and purple coneflower were sterilized with $10 \%$ sodium hypochlorite for $10 \mathrm{~min}$ and after soaked in distilled water. Seeds were sowed in polypropylene plastic pots, having a conical trunk shape $(12.0 \mathrm{~cm}$ high, $9.5 \mathrm{~cm}$ lower diameter, $14.0 \mathrm{~cm}$ upper diameter) and a volume of $1.3 \mathrm{~cm}^{3}$, filled with green 
compost mixed with an inorganic mineral base of perlite and autoclaved at $121^{\circ} \mathrm{C}$ for $3 \mathrm{~h}$ before use.

Substrate physicochemical properties were the following: moisture content $=$ $63.0 \%(\mathrm{w} / \mathrm{w}), \mathrm{pH} 6.63$, total organic carbon $=31.1 \%(\mathrm{w} / \mathrm{w}),{ }^{14}$ total nitrogen $=2.10 \%$ (w/w), ${ }^{15} \mathrm{C} / \mathrm{N}=14.8$. An optimum moisture content in the pots was guaranteed by watering when necessary.

After 80 days from sowing and based on UV-C irradiation time $(0,10,30,60$ and $120 \mathrm{~min})$, the plants were divided in five treatments of 10 plants each. One set for each species served as control, while the other sets were irradiated with UV-C for 10 , 30, 60 and $120 \mathrm{~min}$, respectively. During the whole experiment, except for the irradiation times, plants were maintained under controlled conditions at a constant temperature of $20 \pm 2^{\circ} \mathrm{C}$ with a $16 \mathrm{~h}$ photoperiod and were watered with distilled water when necessary. Fresh and dry weight, the latter determinate after drying the seedlings at $80^{\circ} \mathrm{C}$ until having a constant weight, were recorded immediately before the irradiation and at 21 days after irradiation.

\section{UV-C irradiation}

Ultraviolet light experiments were conducted in controlled conditions, using an irradiation chamber $(0.82 \times 0.52 \times 0.68 \mathrm{~m})$ coated with aluminum sheets and equipped with an UV-C lamp (Helios Italquartz, Milan, Italy; model G15T8; characteristics: $15 \mathrm{~W}, 3.8 \mathrm{~J} \mathrm{~m}^{-2}$ at $1 \mathrm{~m}$ of distance). ${ }^{16}$

\section{Chlorophyll measurement}

Throughout the experiment, measurements on the leaf areas for each species were carried out with a chlorophyll meter SPAD-502 (Konica Minolta; Osaka, Japan) across the whole surface of leaves (on the same area for all data points). The mean values were calculated using the internal function of the chlorophyll meter and expressed in SPAD units.

\section{Gas exchange}

Measurements of net assimilation $(A)$, transpiration $(E)$, stomatal resistance $\left(g_{\mathrm{s}}\right)$ and intercellular $\mathrm{CO}_{2}$ concentration $\left(C_{\mathrm{i}}\right)$ were carried out at the before and $2 \mathrm{~h}$ after of the UV-C treatments, 80 days after sowing on apical mature leaves, well exposed to radiation.

Measurements were carried out using a LI-6400 portable photosynthesis system equipped with a $2-\mathrm{cm}^{2}$ chamber and $6400-$ 40 LED light source, operating at a 380 ppm $\mathrm{CO}_{2}$ concentration. The cuvette humidity and the temperature were kept constant during measurements in order to maintain constant air vapor pressure difference. Analyses were carried out between 12:00 and 14:00 $\mathrm{h}$ (solar time) under saturating light conditions (PAR about $1500 \mu \mathrm{mol}$ photons $\left.\mathrm{m}^{-2} \mathrm{~s}^{-1}\right)$. Measurements were carried out maintaining the leaf temperature near to the air temperature in a temperaturecontrolled growth chamber $\left(28-30^{\circ} \mathrm{C}\right)$.

\section{Statistical analysis}

The experimental design included five treatments for each species arranged in a complete randomized block design with ten measurements from ten different plants, resulting in ten independent replicates $(n=10)$ for each light treatment. Statistical analysis was performed by analysis of variance (ANOVA) with SAS software (SAS Institute; Cary, NC, USA). Fisher's LSD test was performed for the comparison of means at $\mathrm{P} \leq 0.05$.

\section{Results}

As shown in Table 1, the irradiation period has significantly influenced the fresh weight recorded 21 days after irradiation. In particular, for common dandelion the fresh weight decreased from $10.22 \mathrm{~g}$, for the control, to $3.25 \mathrm{~g}$ reached in plants irradiated for $120 \mathrm{~min}$, with a loss of fresh weight of $68.2 \%$. On the other hand, 21 days after irradiation, purple coneflower fresh weight ranged from $5.70 \mathrm{~g}$ (control) to $3.73 \mathrm{~g}$ (120min treatment), with a loss of $34.6 \%$ (half of the value recorded for common dandelion). This trend is clear also for the dry weight measurements (Table 1). The dry matter content was higher in common dandelion, compared to purple coneflower (Table 1). This effect could be explained with a major resistance of purple coneflower to UV-C irradiation.

\section{Chlorophyll measurement}

As shown in Figures 1 and 2, the chlorophyll content measured by mean of the SPAD meter pointed out that for both species the 10 min irradiated samples had a behavior similar to the control respect to the other thesis having a significant reduction of the SPAD values over time. Shoots of both the species exhibited a significant color change during the UV-C exposure, probably due to the photo-oxidation chlorophylls and other pigments.

\section{Gas exchange}

Common dandelion and purple coneflower had a different behavior as regards to the impact of UV-C treatment on gas exchange. Net assimilation $(A)$ in common dandelion deeply decreased in plants

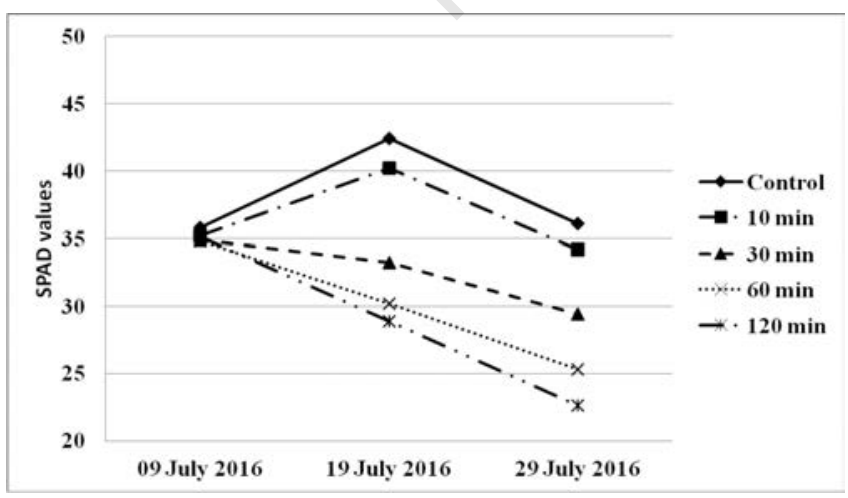

Figure 1. Chlorophyll content variation in common dandelion. Values are means \pm SD of ten independent replicates $(n=10)$ for each light treatment. For each date, mean values followed by a different lowercase letter are significantly different at $\mathbf{P} \leq \mathbf{0 . 0 5}$, according to Fisher's LSD test.

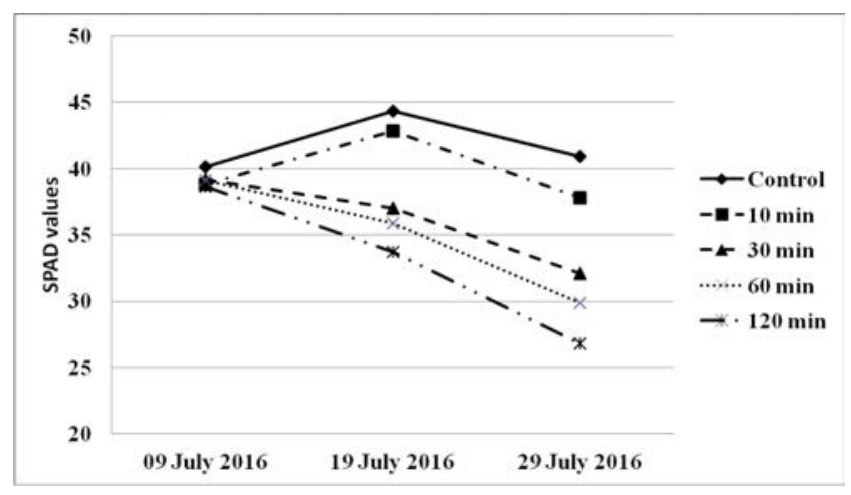

Figure 2. Chlorophyll content variation in purple coneflower. Values are means \pm SD of ten independent replicates $(n=10)$ for each light treatment. For each date, mean values followed by a different lowercase letter are significantly different at $P \leq 0.05$, according to Fisher's LSD test. 
exposed to UV-C for $10\left(1.3 \mu \mathrm{mol} \mathrm{CO}_{2} \mathrm{~m}^{-2}\right.$ $\left.\mathrm{s}^{-1}\right) \min , 30 \mathrm{~min}\left(3.0 \mu \mathrm{mol} \mathrm{CO} \mathrm{CO}^{-2} \mathrm{~s}^{-1}\right), 60$ $\min \left(2.9 \mu \mathrm{mol} \mathrm{CO} \mathrm{CO}^{-2} \mathrm{~s}^{-1}\right)$ and $120 \mathrm{~min}$ (3.4 $\mu \mathrm{mol} \mathrm{CO} \mathrm{CO}_{2} \mathrm{~m}^{-2} \mathrm{~s}^{-1}$, compared to the control $\left(5.6 \mu \mathrm{mol} \mathrm{CO} \mathrm{CO}_{2} \mathrm{~m}^{-1}\right.$ ) (Table 2). In purple coneflower, $A$ had the same pattern measured in common dandelion except that for the longer duration of the treatment (120 min) in which we measured only a slight reduction of photosynthesis respect to the control, 5.7 and $6.5 \mu \mathrm{mol} \mathrm{CO}_{2} \mathrm{~m}^{-2} \mathrm{~s}^{-1}$, respectively. Regarding transpiration $(E)$, in common dandelion it deeply decreased in all the treatments, compared to the control, while in purple coneflower it decreased in all the treatments excepting for the 120-min treatment, as seen for $A$ trend (Table 2).

In common dandelion, stomatal conductance $\left(g_{\mathrm{s}}\right)$ decreased from $0.23 \mu \mathrm{mol} \mathrm{m}^{-2}$ $\mathrm{s}^{-1}$ in control plants to $0.12 \mu \mathrm{mol} \mathrm{m} \mathrm{m}^{-2} \mathrm{~s}^{-1}$ in the 120 -min treatment. In purple coneflower, $g_{\mathrm{s}}$ decreased from $0.17 \mu \mathrm{mol} \mathrm{m}^{-2} \mathrm{~s}^{-1}$ in control plants to $0.09 \mu \mathrm{mol} \mathrm{m} \mathrm{m}^{-2} \mathrm{~s}^{-1}$ in the 60-min treatment, while in the 120 -min treatment it was not significantly different from the control values (Table 2), indicating that stomata were still open. In both plant species, photosynthetic apparatus was affected by UV-C treatment, as shown by the high $C_{\mathrm{i}}$ values measured (Table 2).

The modification of the gas exchange parameters observed on both species indicates that the functioning of the photosynthetic apparatus is strongly compromised, as demonstrated by other authors, even if in other plant species. ${ }^{17}$ Photosynthesis decreases for both stomatal $\left(g_{\mathrm{s}}\right)$ and non-stomatal inhibition $(A)$, as already observed on tomato. ${ }^{16}$ While photosynthesis being compromised in both species, from the comparison between the two species emerged a greater capacity of purple coneflower in the 120-min treatments to maintain the stomata opened, continuing to exchange $\mathrm{CO}_{2}$ with the water vapor. As ours are preliminary results, they need to be confirmed, since the effects on plants submitted to UV-C light depends on the frequency, the duration, the dose and the wavelengths of the UV-C treatments. ${ }^{18}$

\section{Discussion and Conclusions}

This study demonstrated that an exposition of two wild plant species to enhanced levels of UV-C radiation determine important alterations in their growth and physiology. Indeed, physiological and structural alterations were observed in shoots of common dandelion and purple coneflower.

In consideration of the recent possibility of using UV-C radiation able to induce the synthesis and accumulation of health-promoting phytochemicals of nutraceutical importance in plants and to extend shelf life of fresh plant products, ${ }^{19,20}$ it is necessary to better investigate the effect of UV-C radiation on various plant physiological process-

Table 1. Fresh weight, dry weight and dry matter content of common dandelion and purple coneflower seedlings before and after the UV-C treatment.

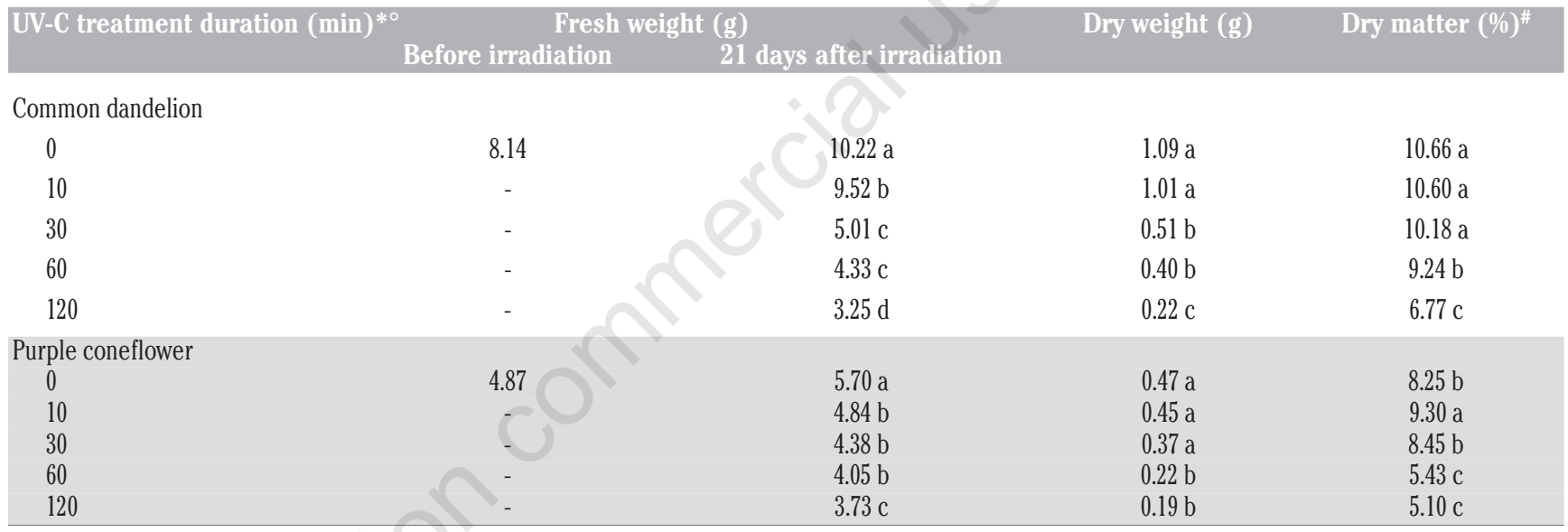

*Values are means \pm SD of ten independent replicates $(\mathrm{n}=10)$ for each light treatment. ${ }^{\circ}$ For each column, mean values followed by a different lowercase letter are significantly different at $\mathrm{P} \leq 0.05$, according to Fisher's LSD test. "The dry matter percentage was calculated on the basis of the fresh weight 21 days after irradiation

Table 2. Net photosynthesis $(A)$, transpiration $(E)$, stomatal conductance $\left(g_{s}\right)$, and intercellular $\mathrm{CO}_{2}(\mathrm{Ci})$ in leaves of common dandelion and purple coneflower seedlings grown under UV-C measured on 31 July 2016.

\begin{tabular}{|c|c|c|c|c|}
\hline UV-C treatment duration $(\mathrm{min})^{* 0}$ & $\begin{array}{c}A \\
\left(\mu \mathrm{mol} \mathrm{CO}_{2} \mathrm{~m}^{-2} \mathrm{~s}^{-1}\right)\end{array}$ & $\begin{array}{c}E \\
\left(\mathrm{mmol} \mathrm{H} \mathrm{O}_{2} \mathrm{~m}^{-2} \mathrm{~s}^{-1}\right)\end{array}$ & $\stackrel{g_{s}}{\left(1 \mathrm{~mol} \mathrm{~m}^{-2} \mathrm{~s}^{-1}\right)}$ & $\begin{array}{c}C_{i} \\
\left(\mu \mathrm{L} \mathrm{L}^{-1}\right)\end{array}$ \\
\hline \multicolumn{5}{|l|}{ Common dandelion } \\
\hline 0 & $5.6 \mathrm{a}$ & $6.2 \mathrm{a}$ & $0.23 \mathrm{a}$ & $342 \mathrm{a}$ \\
\hline 10 & $1.3 \mathrm{e}$ & $1.6 \mathrm{c}$ & $0.04 c$ & $329 \mathrm{a}$ \\
\hline 30 & $3.0 \mathrm{c}$ & $2.7 \mathrm{~b}$ & $0.06 \mathrm{c}$ & $294 \mathrm{~b}$ \\
\hline 60 & $2.9 \mathrm{~d}$ & $3.8 \mathrm{~b}$ & $0.11 \mathrm{~b}$ & $325 \mathrm{a}$ \\
\hline 120 & $3.4 \mathrm{~b}$ & $3.7 \mathrm{~b}$ & $0.12 \mathrm{~b}$ & $319 a$ \\
\hline \multicolumn{5}{|l|}{ Purple coneflower } \\
\hline 0 & $6.5 \mathrm{a}$ & $4.9 \mathrm{a}$ & $0.17 \mathrm{a}$ & $305 \mathrm{a}$ \\
\hline 10 & $2.0 \mathrm{c}$ & $2.7 \mathrm{bc}$ & $0.09 \mathrm{~b}$ & $275 b$ \\
\hline 30 & $2.5 \mathrm{c}$ & $2.6 \mathrm{bc}$ & $0.07 \mathrm{~b}$ & $336 \mathrm{a}$ \\
\hline 60 & $2.9 \mathrm{c}$ & $3.0 \mathrm{~b}$ & $0.09 \mathrm{~b}$ & $329 \mathrm{a}$ \\
\hline 120 & $5.7 \mathrm{~b}$ & $5.5 \mathrm{a}$ & $0.20 \mathrm{a}$ & $332 \mathrm{a}$ \\
\hline
\end{tabular}

*Values are means $\pm \mathrm{SD}$ of ten independent replicates $(\mathrm{n}=10)$ for each light treatment. ${ }^{\circ}$ For each column, mean values followed by a different lowercase letter are significantly different at $\mathrm{P} \leq 0.05$, according to Fisher's LSD test. 
es and particularly on photosynthesis, given its crucial role in plant growth and development. Next steps foresee physiological, genetic and molecular investigations and studies on the possible tolerance mechanisms of common dandelion and purple coneflower to face UV-C radiation. In particular, interest should be directed to the study of antioxidant enzymatic and nonenzymatic compounds and DNA repair mechanisms. Moreover, it could be also important to define the most effective doses of UV-C radiation to obtain beneficial effects on plants.

\section{References}

1. Nawkar GM, Maibam P, Park JH, et al. UV-Induced cell death in plants. Int $\mathrm{J}$ Mol Sci 2013;14:1608-28.

2. Siddiqui A, Dawar S, Javed Zaki M, Hamid N. Role of Ultra Violet (UV-C) radiation in the control of root infecting fungi on groundnut and mung bean. Pak J Botany 2011;43:2221-4.

3. Sofo A, Castronuovo D, Lovelli S, et al. Growth patterns of tomato plants subjected to two non-conventional abiotic stresses: UV-C irradiations and electric fields. In: Ahmad P, Wani MR (eds.). Physiological mechanisms and adaptation strategies in plants under changing environment. 2014;2:285-96.

4. Booij-James IS, Dube SK, Jansen MAK, et al. Ultraviolet-B radiation impacts light-mediated turnover of the photosystem II reaction center heterodimer in Arabidopsis mutants altered in phenolic metabolism. Plant Physiol
2000;124;1275-83.

5. ICNIRP International Commission on Non-Ionizing Radiation Protection (2007), Protecting Workers from Ultraviolet Radiation. Available from: http://www.who.int/uv/publications/Pro tecting_Workers_UV_pub.pdf

6. Kovács E, Keresztes A. Effect of gamma and UV-B/C radiation on plant cells. Micron 2002;33:199-210.

7. Häder DP, Kumar HD, Smith RC, Worrest RC. Effects of solar UV radiation on aquatic ecosystems and interactions with climate change. Photochem Photobiol Sci 2007;6:267-85.

8. Kataria S, Guruprasad KN. Solar UV-B and UVA/B exclusion effects on intraspecific variations in crop growth and yield of wheat varieties. Field Crops Res 2012;125:8-13.

9. Müller-Xing R, Xing Q, Goodrich J. Footprints of the sun: memory of UV and light stress in plants. Front Plant Sci 2014;5:474.

10. Schütz K, Carle R, Schieber A. Taraxacum - A review on its phytochemical and pharmacological profile. J Ethnopharmacol 2006;107:313-23.

11. Sultan MT, Butt MS, Qayyum MM, Suleria HA. Immunity: plants as effective mediators. Crit Rev Food Sci Nutr 2014;54:1298-308.

12. Hudson JB. Applications of the phytomedicine Echinacea purpurea (purple coneflower) in infectious diseases. J Biomed Biotechnol 2012;769896.

13. Castronuovo D, Sofo A, Lovelli S, et al. Light spectrum affects growth and gas exchange of common dandelion and purple coneflower seedlings. Int J Plant Biol 2016;7:11-4.
14. Nelson DW, Sommers LE. Total carbon, organic carbon and organic matter. In: Page AL, Miller RH, Keeney DR, eds. Methods of soil analysis. Part II. Madison: American Society of Agronomy SSSA Publisher; 1982. pp. 539-579.

15. Bremner JM, Mulvaney CS. Nitrogen total. In: Page AL, Miller RH, Keeney DR, eds. Methods of soil analysis. Part II. Madison: American Society of Agronomy SSSA Publisher; 1982. pp. 595-624.

16. Castronuovo D, Tataranni G, Lovelli S, et al. UV-C irradiation effects on young tomato plants: preliminary results. Pak J Botany 2014;46:945-9.

17. Rahimzadeh J, Meng F, Sachs F, et al. Real-time observation of flow-induced cytoskeletal stress in living cells. Am J Physiol Cell Physiol 2011;301:C64652.

18. Pontin M, Piccoli P, Francisco R, et al. Transcriptome changes in grapevine (Vitis vinifera L.) cv. Malbec leaves induced by ultraviolet-B radiation. BMC Plant Biol 2010;10:224.

19. Bridgen MP. Using ultraviolet-C (UVC) irradiation on greenhouse ornamental plants for growth regulation. In: VIII International Symposium on Light in Horticulture 2016. 1134. pp. 49-56.

20. Urban L, Charles F, de Miranda MRA, Aarrouf J. Understanding the physiological effects of UV-C light and exploiting its agronomic potential before and after harvest. Plant Physiol Biochem 2016;105:1-11. 